\title{
The efficacy of cervical encerclage on the course of labour in well selected cases: a prospective study at a tertiary care hospital
}

\author{
Kunaal K. Shinde*, Anand V. Karale, Gulabsingh Shekhawat, Hiralal Shivale
}

Department of Obstetrics and Gynecology, Smt. Kashibai Navale Medical College and General Hospital, Narhe, Pune, Maharashtra, India

Received: 04 July 2017

Accepted: 07 July 2017

*Correspondence:

Dr. Kunaal K. Shinde,

E-mail: dr.kunaal.shinde@gmail.com

Copyright: () the author(s), publisher and licensee Medip Academy. This is an open-access article distributed under the terms of the Creative Commons Attribution Non-Commercial License, which permits unrestricted non-commercial use, distribution, and reproduction in any medium, provided the original work is properly cited.

\begin{abstract}
Background: The two major problems for modern obstetrics and perinatal medicine are recurrent second trimester abortions and preterm delivery. Cervical insufficiency or incompetency is defined as the inability of the uterine cervix to retain a pregnancy in the absence of contractions or labor. Cervical encerclage is a simple but a resourceful procedure for improving the fetal outcome in cases proven with cervical incompetence, is a boon to modern obstetrics.

Methods: A prospective analytical study was carried out at tertiary care teaching hospital for a period of ten years. Three hundred and twenty cases of bad obstetric history (repeated abortions, preterm labor) with previous pregnancy losses probably due to cervical incompetence or ultrasonographical evidence of short cervix were included in the study. These cases were subjected to cervical encerclage operation in the second trimester.

Results: Out of the 289 cases, who underwent McDonald's procedure, 12 women had abortion, 66 had preterm labor and 211 women reached term. Out of the 31 cases who underwent Wurm's procedure; 4 had abortion, 17 had preterm delivery and 10 women reached to term. In the present study, the average interval from cerclage to delivery was 115 days. It was observed that the fetal salvage rate was unsatisfactory in women having short cervix with open internal os before encirclage. Infant salvage rate in this study after encerclage operation was $86 \%$.

Conclusions: Cervical encerclage when done in properly selected cases, results in improvement in fetal salvage up to eighty percent.
\end{abstract}

Keywords: Cervical encerclage, Cervical incompetence, Preterm labor, Recurrent abortions

\section{INTRODUCTION}

Recurrent second trimester abortions and preterm delivery, continue to haunt as two major problems for modern obstetrics and perinatal medicine. Cervical insufficiency or incompetency is defined as the inability of the uterine cervix to retain a pregnancy in the absence of contractions or labor. ${ }^{1}$ It is characterized by a painless opening and shortening of the cervix uteri between 16 to 28 weeks of gestation resulting in pregnancy wastage. ${ }^{2}$ This operation for repair of cervical internal os was first described by Palmer and Lacomme. ${ }^{3}$ Lash and Lash published a paper on habitual abortions due to cervical incompetence. ${ }^{4}$ Shirodkar described his new operative technique for managing cervical incompetence. ${ }^{5}$

The incidence reported by various authors for this entity differs from 1:54 to 1:222 pregnancies. ${ }^{6-9}$ In the second trimester, it is responsible for $15-20 \%$ of the total abortions. Cervical encerclage is considered as a simple but useful minor surgical procedure for improving the fetal salvage in proven cases of cervical incompetence. 


\section{METHODS}

A prospective analytical study was carried out at a tertiary care teaching hospital for a period of ten years. Three hundred and twenty cases of bad obstetrical history (repeated abortions, preterm labor) with previous pregnancy losses probably due to cervical incompetence or ultrasonographical evidence of short cervix were included in the study.

The inclusion criteria for diagnosis of cervical incompetence on past reproductive history, transvaginal ultrasonography findings or clinical examination of the current pregnancy. The cases were subjected to cervical encerclage operation at various gestational periods. All women were given tocolytic therapy till 37 weeks of pregnancy. Cervical stitch was removed at 38 weeks of gestation. All the women were counselled and advised mandatory institutional delivery. Written informed consent of all the patients was taken in local language.

\section{RESULTS}

The majority of the cases were in the peak reproductive age group $(93 \%)$. A total of $83 \%$ of the cases were unbooked at the time of admission. Eighty seven percent were multigravidas (Table 1).

Table 1: General observations.

\begin{tabular}{|ll|}
\hline Age $20-30$ years & Percent \\
\hline Unbooked cases & 93.4 \\
\hline Multigravida & 82.8 \\
\hline
\end{tabular}

In the present study of 320 cases, the average cerclage to delivery interval was 115 days. In $70 \%$ cases, there were some associated risk factors responsible for cervical incompetence. Previous preterm delivery or abortions were present in $45 \%$ cases (Table 2 ).
Table 2: Predisposing factors for cervical incompetence.

\begin{tabular}{|ll|}
\hline Predisposing factor & No. of patients \\
\hline Previous manchester operation & 7 \\
\hline Cervical tear & 9 \\
\hline Difficult breech delivery & 6 \\
\hline MTP & 38 \\
\hline Previous preterm delivery & 80 \\
\hline Previous abortions & 64 \\
\hline Twin pregnancy & 17 \\
\hline Hydramnios & 3 \\
\hline
\end{tabular}

Sixty four percent of cases presented in late second trimester (Table 3). Out of the 289 women who underwent McDonald's procedure, 12 women had abortion, 66 had preterm delivery and 211 women reached term. Of the 66 women preterm women, 47 had Preterm vaginal delivery, 7 had Preterm vaginal forceps delivery and 12 underwent LSCS.

Table 3: Gestational age at the time of cerclage.

\begin{tabular}{|llll|}
\hline Gestation & No. of cases & Gestation & No. of cases \\
\hline 14 & 16 & 24 & 62 \\
\hline 16 & 21 & 26 & 80 \\
\hline 18 & 31 & 28 & 21 \\
\hline 20 & 33 & 30 & 29 \\
\hline 22 & 11 & 32 & 16 \\
\hline
\end{tabular}

The LSCS were for obstetric causes with POM with failed induction in 4 cases, IUGR in 3 cases and fetal distress in 5 cases. Out of the 211 term patients, 165 delivered spontaneously, 34 underwent LSCS and 12 had forceps vaginal delivery. Cesarean section was done for obstetric indications like CPD in 7 , breech in 4 cases, cervical dystocia in 3 cases, failed induction in 13 cases and fetal distress in 7 cases.

Table 4: Methods of encerclage and pregnancy outcome.

\begin{tabular}{|c|c|c|c|c|c|c|c|c|}
\hline \multirow{3}{*}{$\begin{array}{l}\text { Method of } \\
\text { encerclage }\end{array}$} & \multirow{3}{*}{$\begin{array}{l}\text { No. of } \\
\text { cases }\end{array}$} & \multicolumn{7}{|c|}{ Pregnancy outcome } \\
\hline & & \multirow{2}{*}{ Abortion } & \multicolumn{6}{|c|}{ Delivery } \\
\hline & & & SVD & PTVD & LSCS & PT LSCS & Forceps & PT Forceps \\
\hline McDonald's & 289 & 12 & 165 & 47 & 34 & 12 & 12 & 7 \\
\hline Wurm's & 31 & 4 & 7 & 9 & 1 & 7 & 2 & 1 \\
\hline Total & 320 & 16 & 172 & 56 & 35 & 19 & 14 & 8 \\
\hline
\end{tabular}

Out of all the 277 deliveries, 293 neonates were delivered, as 17 women had twin gestation and one woman of those twins had twin with one fetal demise. Out of 293 babies, 20 babies died, 9 died due to prematurity and respiratory distress syndrome, 3 died due to fetal distress and 8 died due to septicemia. In the group of 31 women who underwent Wurm's procedure, 4 women aborted, 17 had preterm deliveries and 10 reached term. Of the 17 preterm deliveries, 9 had preterm vaginal delivery, 7 had preterm LSCS and 1 had preterm forceps vaginal delivery. The cesarean section was done for 
PROM with failed induction in 4 cases and fetal distress in 3 cases. Out of the 10 cases that reached term, 7 had spontaneous vaginal delivery, 1 had cesarean section for fetal distress and 2 patients had forceps vaginal delivery.
Out of 27 babies delivered, 11 babies died in this group. Seven neonatal deaths were due to prematurity and respiratory distress syndrome, and 4 were due to septicemia.

Table 5: Condition of cervix at encerclage and pregnancy outcome.

\begin{tabular}{|c|c|c|c|c|c|c|c|}
\hline \multirow{3}{*}{$\begin{array}{l}\text { Pregnancy } \\
\text { outcome }\end{array}$} & \multirow{3}{*}{$\begin{array}{l}\text { Total } \\
\text { cases } \\
(320)\end{array}$} & \multicolumn{6}{|c|}{ Condition of cervix } \\
\hline & & \multirow{2}{*}{$\begin{array}{l}\text { Os closed, } \\
\text { Open canal } \\
\text { Short cervix }\end{array}$} & \multicolumn{5}{|l|}{ Os open } \\
\hline & & & Long canal & Short canal & Ripe cervix & 1 finger loose & 2 fingers loose \\
\hline Abortion & 16 & -- & -- & 9 & -- & 7 & -- \\
\hline Preterm labor & 83 & 3 & 7 & 13 & 21 & 23 & 16 \\
\hline $\begin{array}{l}\text { Term } \\
\text { pregnancy }\end{array}$ & 221 & 34 & 24 & 40 & 33 & 67 & 23 \\
\hline Total & 320 & 37 & 31 & 62 & 54 & 97 & 39 \\
\hline
\end{tabular}

The overall cesarean section rate was 18 percent in the study (Table 4). It was observed that more the cervical dilatation at the time of encerclage, worse was the pregnancy outcome (Table 5). Complications were noticed in 22 cases following cerclage. Commonest of them being displacement of suture following encerclage. In 14 cases, uterine irritability was increased following cerclage, which was managed by intravenous tocolytic drugs; one case had PROM and three cases had chorioamnionitis each.

\section{DISCUSSION}

The term cervical incompetence was used for the first time by Gream. ${ }^{10}$ Romero and others suggested the term cervical insufficiency in order to avoid the negative connotation that the term incompetence implies on the patients. Cervical cerclage was introduced by Shirodkar and was first performed on women who had at least 4 abortions or was confined to women in whom he could prove the existence of weakness of the internal os by repeated internal examinations. ${ }^{5}$ McDonald suggested a simplification, and after that, now there exists a variety of modifications. ${ }^{12}$ Incompetent cervical os is the recognized cause of repeated mid trimester abortions ad early preterm labour. Incidence of cervical incompetence in the present study was $1.12 \%$ of the antenatal admissions, which was more than what was observed by the other authors (Stromme and Haywa reported the incidence varying from $0.05 \%$ to $1 \%) .{ }^{13}$ The higher incidence in the rural area could be because of the cervical trauma during unattended home deliveries.

In this study, $70 \%$ cases had a previous history suggestive of iatrogenic cervical injury. According to McDonald, congenital defects of the cervix are rare. They are responsible for no more than $2 \%$ of all cases of cervical incompetence. ${ }^{12}$ In the present study, $12 \%$ women were nulliparous. There is still a controversy regarding treatment of cervical incompetence. Surgical management has been adopted as the mainstay of treatment. Variety of techniques for encerclage have been tried in the past. In the present study, overall success rate was $88 \%$. Golan reported improvement following encerclage in fetal survival rate from $69 \%$ to $92 \% .{ }^{14}$ Even though, cervical incompetence has been an accepted entity now, its relationship to open cervical os is still debatable. Floyd, Anderson and Turnball and various others have not found any significant change in outcome of labor in patients having open cervical os. ${ }^{15,16}$ Wood et al and many others have shown increase in preterm labor in patients with an open os. Value of internal examination to detect weak shorter os is emmence. ${ }^{17}$ The last decade in particular has seen a decrease in the usage of cerclage. ${ }^{3}$ In contrast to the early days of cerclage, a cerclage is performed today either prophylactically and electively, according to the history of the patient or due to findings within the present pregnancy, or therapeutically, in cases with significant opening or shortening of the cervix. Although encerclage has been performed quite frequently, it always has been a subject to controversy. Harger and the ACOG Practice Bulletin have given a good overview. ${ }^{18,19}$ Randomized studies with encerclage have not proven to be of benefit for women with low risk of preterm delivery (by history). ${ }^{20}$ The effectiveness in women with high risk pregnancies is uncertain. For example, Rush could not find any significant difference. ${ }^{21}$ The MRC/RCOG final report on encerclage did find a significant difference only in one of the six subgroups, namely with regard to births under 33 weeks gestation in the subgroup of women with 3 or more second trimester miscarriages or preterm births in history. ${ }^{22}$ More current research tried to identify women who might benefit from encerclage by monitoring the cervical length and performing an encerclage only when the cervix is short or shortening. Although initial studies had been promising more recent studies do not support this. ${ }^{23-26}$ Hassan et al. could even show in a retrospective cohort study, that, in 
patients with a shortened cervix $(\leq 15 \mathrm{~mm})$, cervical encerclage did not only not reduce the rate of preterm delivery but it did increase the risk of preterm rupture of membranes. ${ }^{27}$ Obido et al compared Shirodkar versus McDonald encerclage in women with a short cervix and found no significant difference in the prevention of preterm delivery. ${ }^{28}$ Romero et al conclude in their review: The role of prophylactic encerclage in high risk patients without a sonographic short cervix for the prevention of preterm delivery/mid-trimester abortion (by history) is unclear. ${ }^{11}$

Even though we are likely to overdo cervical encerclage, especially in multiparous women with open os, it is better on the safer side by doing encerclage in borderline cases rather than waiting till the onset of preterm labor. This is because even though diagnosis of incompetent os is still debatable, value of cervical encerclage by McDonalds or other procedure have been firmly established without any debate because of consistently improved infant salvage rate as reported by various workers. ${ }^{6-9}$

\section{CONCLUSION}

Cervical encerclage in appropriately selected cases, in early second trimester of pregnancy can improve fetal salvage rate up to $80 \%$. Proper history taking aided with good clinical and sonographic evaluation of cervix, can guide in the selection of patients for prophylactic cerclage, thereby increasing the carry home baby rate. Today, encerclage operations present as a medical boon to women previously denied children because of incompetent cervix.

\section{Funding: No funding sources}

Conflict of interest: None declared

Ethical approval: The study was approved by the Institutional Ethics Committee

\section{REFERENCES}

1. American College of Obstetricians and Gynecologists (2004): ACOG Practice Bulletin. Cervical insufficiency. Int $\mathrm{J}$ Gynaecol Obstet. 2004;85:81-9.

2. Vetter K, Kilavuz Ö. Cervical insufficiency: operative possibilities. Gynäkologe. 2001;34:726-31.

3. Palmer R, Lacomme M. The Bean of the internal orifice, cause of abortions has petition? An observation of cervical ischemic cervical surgery, surgically, with consecutive tear. Gynecol Obstet. 1948;47:904.

4. Lash AF, Lash AR. Habitual abortions: The incompetent internal os of the cervix. Am J Obstet Gynecol. 1950;59:68.

5. Shirodkar VN. A new method of operative treatment for habitual abortions in the second trimester of pregnancy. Antiseptic. 1955,52:299.
6. Kuhn RJ, Pepperell RJ. Cervical ligation: A review of 242 pregnancies. Aust N Z J Obstet Gynecol. 1977; 17:79.

7. Harger $\mathrm{JH}$, Comparision of success and morbidity in cervical cerclage procedures. Obstet Gynecol. 1980;56:543.

8. Lidegaard O. Cervical encerclage in Denmark 19801990. A register based epidemiological survey. Acta Obstet Gynecol Scand. 1994;73:35.

9. Toaff R, Toaff ME, Ballas S, Ophir A. Cervical incompetence: Diagnostic and therapeutic aspects. Isr J Med Sci. 1977;13:39-49.

10. Gream GT. Dilatation or division of the cervix uteri. Lancet. 1865;1:381

11. Romero R, Espinoza J, Erez O, Hassan S. The role of cervical cerclage in obstetric practice: Can the patient who could benefit from this procedure be identified? Am J Obstet Gynecol. 2006;194:1-9.

12. McDonald JA. Suture of the cervix for the inevitable miscarriage. J Obstet Gynecol. 1957;64:346.

13. Stromme WB, Haywa EB. Intrauterine foetal death in second trimester. Am J Obstet Gynecol. 1963;85:225.

14. Golan A Barnan R, Wexler S, Langer R, Bukovsky I, David MP. Incompetence of the uterine cervix. Obstet Gynaec Surv. 1989;44:96.

15. Floyd WS. Cervical dilatation in midtrimester of pregnancy. Obstet Gynecol. 1961;27:130.

16. Anderson ABM, Turnball AC. Relationship between length of gestation and cervical dilatation in ultrasonographic evaluation of cervical incompetence. Am J Obstet Gynecol. 1969;105:1207.

17. Wood C, Bonnerman RHO, Booth KT, Pinkerton JH. Prediction of preterm labour by observation of cervix and external tocography. Am J Obstet Gynecol. 1965;91:396.

18. Harger JH. Comparision of success and morbidity in cervical cerclage procedures. Obstet Gynecol. 1980;56:543.

19. American College of Obstetricians and Gynaecologists: ACOG Practice Bulletin. Cervical insufficiency. Int J Gynecol Obstet. 2004;85:81-9.

20. Drakeley AJ, Roberts D, Alfirevic Z. Cervical cerclage for prevention of preterm delivery: metaanalysis of randomized trials. Obstet Gynecol. 2004;102(3):621-7.

21. Rush RW, Isaacs S, McPherson K, Jones L, Chalmers I, Grant A. A randomized controlled trial of cervical cerclage in women at high risk of spontaneous preterm delivery. Br J Obstet Gynaecol. 1984;91(8):724-30.

22. MRC/RCOG Working Party on Cervical Cerclage. Final report of the medical research council/ royal college of obstetricians and gynaecologists multicenter randomized trial of cervical cerclage. $\mathrm{Br}$ J Obstet Gynaecol. 1993;100:516-23.

23. Berghella V, Haas S, Chervoneva I, Hyslop $T$. Patients with prior second trimester loss: prophylactic cerclage or serial transvaginal 
sonograms: Am J Obstet Gynaecol. 2003;187(3):747-51.

24. To MS, Palaniappan V, Skentou C, Gibb D, Nicolaides KH. Elective cerclage vs Ultrasound indicated cerclage in high-risk pregnancies. Ultrasound Obstet Gynecol. 2002;19(5):475-7.

25. Belej-Rak T, Okun N, Windrim R, Ross S, Hannah ME. Effectiveness of cervical cerclage for a sonographically shortened cervix: a systematic review and metaanalysis. Am J Obstet Gynecol. 2003;189(6):1679-87.

26. To MS, Alfirevic Z, Heath VC, Cicero S, Caho AM, Willamson PR, Nicolaides KH. Fetal Medicine Foundation Second Trimester Screening Group. Cervical cerclage for prevention of preterm delivery in women with short cervix: randomized controlled trial. Lancet. 2004;363:1849-53.
27. Hassan SS, Romero R, Maymon E, Berry Sm, Blackwell SC, Treadwell MC, Tomlinson M. Does cervical cerclage prevent preterm delivery in patients with a short cervix? Am J Obstet Gynaecol. 2001;184:1325-9.

28. Odibo Ao, Berghella V, To MS, Rust OA, Althuisius SM, Nicolaides KH. Shirodkar versus McDonald cerclage for the prevention of preterm birth in women with short cervical length. Am J Perinatol. 2007;24(1):55-60.

Cite this article as: Shinde KK, Karale AV, Shekhawat G, Shivale H. The efficacy of cervical encerclage on the course of labour in well selected cases: a prospective study at a tertiary care hospital. Int J Reprod Contracept Obstet Gynecol 2017;6:3319-23. 